IJ§ER

ISSN: 2149-5939
International Journal of Social Sciences and Education Research

Online, https://dergipark.org.tr/tr/pub/ijsser

Volume: 8(2), 2022

\title{
Determination of special education teachers' knowledge levels on the behavioral intervention techniques
}

\author{
Şeyda Dellaloğlu Göğebakan ${ }^{1}$ and Elif Sazak ${ }^{2}$ \\ ${ }^{I}$ T.C. Millî Eğitim Bakanlığl, Beşiktaș Rehberlik ve Araștırma Merkezi, İstanbul, Turkey, e-mail: seydadellaloglu@hotmail.com ORCID: \\ https://orcid.org/0000-0001-5418-5950 \\ ${ }^{2}$ Corresponding author, Bolu Abant İzzet Baysal University, Education Faculty, Bolu, Turkey, e-mail: elifsazak@hotmail.com, ORCID: \\ https://orcid.org/0000-0003-3530-9588
}

\begin{tabular}{|c|c|}
\hline Article Info & Abstract \\
\hline $\begin{array}{l}\text { Received: } 12 \text { December } 2021 \\
\text { Revised: } 30 \text { January } 2022 \\
\text { Accepted: } 22 \text { February } 2022 \\
\text { Keywords: } \\
\text { Special education teachers, } \\
\text { Behavioral treatment, } \\
\text { Behavioral intervention tech- } \\
\text { niques, } \\
\text { Knowledge test }\end{array}$ & $\begin{array}{l}\text { This research aims to determine the knowledge levels of special education teachers on the } \\
\text { behavioral intervention techniques that are commonly used during the behavioral treatment } \\
\text { of their students and to examine whether the demographic variables have effects on teach- } \\
\text { ers' knowledge levels or not. Within the scope of research, data was collected from } 295 \\
\text { special education teachers from } 10 \text { different cities. The data is collected through the } \\
\text { Knowledge Test of Frequently Used Behavioral Intervention Techniques (F-BIT) and De- } \\
\text { mographic Information Forms that are already developed, valid, and reliable by the re- } \\
\text { searcher. Later on, the data has been analyzed through descriptive statistical techniques. As } \\
\text { for the results, the lowest grade that is obtained from the knowledge test was } 5 \text { and the } \\
\text { highest was } 30 \text { while the average was } 21 \text { and the standard deviation was } 4,74 \text {. During the } \\
\text { research, it has been determined that knowledge levels of teachers are limited and gender } \\
\text { does not have any effect on these limited levels. All the results have been discussed in the } \\
\text { context of the importance of behavioral intervention, current conditions, and requirements } \\
\text { of the process. }\end{array}$ \\
\hline
\end{tabular}

\section{Introduction}

Problem behaviors can be defined as behaviors that can be observed frequently in students with normal development and special needs, negatively affect the academic success of the student, participation in the course, social relations and interaction, affect the learning of himself and those around him, and harm himself and his environment (Erbaş, 2002). These behaviors come in many different forms. For example, there may be serious problem behaviors such as self-injury, biting, hitting, and damaging objects, as well as mild problem behaviors such as walking around the classroom, exhibiting ineffective behaviors, or not following instructions (Erbaş, 2002). It is reported that among the most challenging issues that teachers encounter in the classroom daily, problem behaviors exhibited by students are reported (Rose \& Gallup, 2005; Westling, 2010), and there is even evidence that more than $80 \%$ of the teaching time is spent on students' problem behaviors (Simonsen et al., 2010).

Problem behaviors that students frequently exhibit in general education (Aymaz 2018; Çankaya \& Çanakçı 2011; Özer et al., 2014) and special education (Acar, 2000; Alatl1, 2014; Aykır, 2010; Ceylan, 2015; Erbaş, 2001; Güner-Yıldız \& Sazak-Pınar, 2012; Timuçin 2008; Yaşarsoy, 2006) environments; speaking without asking, sitting inappropriately during the lesson, not listening to the lesson, going to the toilet during the lesson, not participating in the activity, hitting each other, going in and out of the classroom without permission, not paying attention to the lesson, lying on the desk, disturbing your friends, talking among themselves, not listening to the person speaking, complaining about your friend pushing is referred to as pushing. It is known that the problem behaviors exhibited by the students in the classroom environment limit the learning opportunities of both themselves and their peers and can negatively affect their behavior patterns (Chandler \& Dahlquist, 2002).

*All responsibility belongs to the researchers. This research has ethical approval from Abant İzet Baysal University, Ethics Committee of Human Researches in Social Sciences (Date: 24.01.2018; Approval: 2018/16)

To cite this article: Dellaloğlu Göğebakan, Ş. \& Sazak, E. (2022). Determination of special education teachers' knowledge levels on the behavioral intervention techniques. International Journal of Social Sciences and Education Research, 8 (2), 120 134. DOI: $\underline{\text { https://doi.org/10.24289/ijsser.1034043 }}$ 
Strategies used according to the behavioral approach in reducing or eliminating problem behaviors are consequence-based strategies. Among these strategies, differential reinforcement, extinction, and response cost are among the moderate techniques (Sazak, 2017). Differential reinforcement can be briefly defined as reinforcing some behaviors while ignoring others. Differential reinforcement types can be classified as; differential reinforcement of incompatible (opposite) behaviors, differential reinforcement of other behaviors, and differential reinforcement of low rates of behaviors. Extinction is a technique that requires the reinforcing of a previously reinforced problem behavior to be stopped, thus reducing the probability of the unreinforced problem behavior to occur in the future, and then eliminating the problem behavior (Cooper, Heron \& Heward, 2007; Sazak, 2017). The cost of the response is the practice of reducing the formation of behaviors as a result of retaining or withdrawing some of the reinforcement possessed due to the display of the problem behavior (Sazak, 2017). Extinction and response cost are among the moderate techniques in the classification made according to the power of control and intervention on the student in reducing the behaviors.

Punishment-based strategies are also included in reducing or eliminating problem behaviors. These strategies, follow a sequence from the more recommended to the less or not recommended to are used among themselves; time-out, overcorrection, and delivering punishing stimulus. Time-out is a technique used to reduce the frequency of problem behavior in problem schools and clinical settings. Time-out can also be defined as isolating the student from the reinforcers that maintain the behavior immediately after the problem behavior is exhibited (Alberto \& Troutman, 2006; Sazak, 2017). Overcorrection, on the other hand, can be defined as overcorrection of the environmental effects of the behavior or excessive display of the correct form of the behavior in the environment in which it appears. The last technique to be used in reducing and eliminating problem behaviors is delivering punishing stimulus. Delivering a punishing stimulus, on the other hand, is the reduction or disappearance of the problem behavior by presenting the impulsive stimulus to the student right after the problem behavior is exhibited (Kircaali-Iftar \& Tekin, 1997). To reduce the problem behavior, it is necessary to choose the most moderate technique first and to try other techniques in cases where the technique is not effective (Kırcaali-İftar \&Tekin, 1997).

Teachers can follow different ways based on their professional knowledge and past experiences in coping with problem behaviors (Erbaş, 2002). On the other hand, the interventions used by teachers are not based on techniques based on behavioral approach. In coping with the problem behaviors of their students, teachers; resort to interventions such as verbal warning, talking with the student outside the classroom, meeting with his/her family, making eye contact, meeting with the school administration, giving him/her unwanted tasks and depriving him/her of what he/she wants; it is stated that none of the behavioral intervention methods that teachers have stated in coping with students' problem behaviors are based on a systematically applied behavior treatment (Sazak-Pınar \& GünerYildız, 2013). The fact that teachers do not use techniques based on behavioral approaches is thought to be because they do not know about these strategies, but the absence of a knowledge test in the literature that can reveal this result also indicates an important deficiency. However, determining the level of knowledge of teachers about behavioral intervention strategies that their students use frequently in behavior treatment will guide the teacher training programs to be prepared. Thus, teachers will increase their level of knowledge about behavioral intervention strategies, which have been determined to be moderately and highly effective in the literature (Beare, Severson \& Brandt, 2004; Chezan, Wolfe \& Drasgow, 2017; Chitiyo et al., 2011; Heyvaert et al., 2014; LeGray et al., 2013; Losinski et al., 2016; Morano et al., 2017; Ritter et al., 2018; Solomon et al., 2012), and they will be able to reduce or eliminate the problem behaviors of students.

When the literature is examined, no study examines the knowledge levels of teachers working in the field of special education about the behavioral intervention techniques that students frequently use in the behavioral treatment of their students. In addition, it is seen that there is no test to measure the knowledge levels of both general and special education teachers about behavioral theory-based behavior intervention techniques. In the literature, the knowledge levels of general education teachers about behavioral intervention were evaluated with a knowledge test prepared within the scope of classroom management (Alatl1, 2014; Güner, 2010; Işıkgöz et al., 2018). For this reason, it cannot be thought that the obtained findings fully test the knowledge levels about behavioral intervention. It is seen that there is a need for tools that will more clearly measure the knowledge level of teachers on the subject. It is thought that the Frequently Used Behavioral Intervention Techniques (F-BIT) Knowledge Test developed in this research will contribute to the literature, and the study is considered important in this respect.

\section{Purpose of this study}

This study, it was aimed to determine the knowledge level of teachers in the field of special education about behavioral intervention techniques that are frequently used in behavioral treatment. In line with this main purpose, answers to the following questions were sought in the study: 
1. What is the knowledge level of teachers in the field of special education about behavioral intervention techniques that are frequently used in behavioral treatment?

2. Do the knowledge levels of the teachers in the special education field about the behavioral intervention techniques that are frequently used in the behavior treatment of their students differ according to their demographic information?

\section{Methods}

Design

This research is a descriptive study designed according to the survey model. Descriptive research means collecting existing information and determining the existing situation, and revealing the information without interfering with the information sources. The survey model, on the other hand, is a model that aims to describe a past or present situation as it is, and is based on the definition of the event, individual, or object that is the subject of the research, in its terms and as it is (Karasar, 1995). Surveys, observations, interviews, inquiries, multiple-choice tests, and open-ended questions are used in descriptive research; prepared tools are used as measurement tools (Sönmez \& Alacapınar, 2016).

In this study, F-BIT Knowledge Test developed within the scope of the research was used to determine the knowledge level of teachers in the field of special education about behavioral intervention techniques that are frequently used in behavioral treatment. The F-BIT Knowledge Test was developed by researchers and consists of questions about behavioral intervention techniques that are frequently used to increase students' appropriate behaviors and reduce-eliminate problem behaviors.

\section{Participants}

The study group of the research consists of 295 teachers in the field of special education in 10 provinces of Turkey. In the determination of the participants, it was taken as a criterion that the teachers were working as special education teachers in the field of special education. The reason for this is that stronger evidence is desired to obtain the content validity and reliability of the developed F-BIT Knowledge Test. Because teachers working in the field of special education are those who graduated from special education and classroom teaching undergraduate programs. Within the scope of the special education teaching undergraduate program, there is a course called "Applied Behavior Analysis" related to behavioral theory-based techniques and "Classroom Management" within the scope of the classroom teaching undergraduate program (Higher Education Institution [YÖK], 2021). In the study, it was aimed to reach a more homogeneous study group rather than the teachers who graduated from the classroom teaching undergraduate program who only work in general education environments. Thus, teachers working in the field of special education, which are graduates of both undergraduate programs, were included in this study.

Table 1. Frequency (f) and percentage (\%) distributions of demographic variables

\begin{tabular}{llcc}
\hline Variable & Categories & $\mathrm{f}$ & $\%$ \\
\hline Gender & Female & 169 & 57,3 \\
& Male & 126 & 42,7 \\
\hline Age & 24 years and under & 53 & 18,0 \\
& $25-35$ years & 187 & 63,4 \\
& 36 years and older & 55 & 18,6 \\
\hline Workplace & Special Education Practice School & 103 & 34,9 \\
& Special Education Business Application Center & 52 & 17,6 \\
& Classroom of Special Education & 66 & 22,4 \\
& Other & 74 & 25,1 \\
\hline Graduated Department & Teacher for Intellectual Disability & 130 & 44,1 \\
& General Education Teacher & 91 & 30,8 \\
& Other & 74 & 25,1 \\
\hline Education on Special Education & Special Education Undergraduate Program & 183 & 62,0 \\
& Other & 112 & 38,0 \\
\hline Education on Behavioral Intervention Techniques & Yes & 212 & 71,9 \\
& No & 83 & 28,1 \\
\hline Total & & 295 & 100,0 \\
\hline
\end{tabular}


It has been tried to ensure that the developed F-BIT Knowledge Test is applied to all teachers working in the field of special education in Turkey, but only 10 provinces responded to the tests. These provinces are; Ankara, Bolu, Bartın, Zonguldak, Bilecik, Istanbul, Mersin, Tekirdağ, Çanakkale and Kahramanmaraş. In the study, data were collected on 10 different demographic variables of teachers, including age, gender, place of work, disability group, age group of students, graduation status, graduated department, education related to special education, years of service, and training in behavioral intervention techniques. To obtain meaningful results from the analyses, the variables of graduation status and years of service, whose distributions are statistically unbalanced, were excluded from them. Since more than one marking could be made in the variables of disability group and student age group studied, each option in the variables was evaluated as a separate question. Information on demographic variables related to teachers is presented in the tables below. The frequency distributions of demographic variables are given in Table 1.

When Table 1 is examined, $57.3 \%$ of the teachers participating in the study are female, $42.7 \%$ are male; $18 \%$ are 24 years old and younger, $63.4 \%$ are $25-35$ years old; $18.6 \%$ are 36 years and older; $34.9 \%$ in special education practice school, $17.6 \%$ in special education business application center, $22.4 \%$ in a special education class, $25.1 \%$ in other institutions; $44.1 \%$ of them are teaching the intellectual disability, $30.8 \%$ are classroom teachers, $25.1 \%$ are from other departments (such as pre-school, teaching for the visually impaired, hearing impaired); $62 \%$ special education license, $38 \%$ other programs; $71.9 \%$ received behavioral intervention training, $28.1 \%$ are not. It is seen that the participants can mark in more than one area. The frequency distributions of the students' age group and disability group variables, in which the teachers work, are given in Table 2.

Table 2. Number of participants in demographic variables with more than one choice (n)

\begin{tabular}{lccc}
\hline Worked disability group & $\mathrm{n}$ & Working student age group & $\mathrm{n}$ \\
\hline Intellectual disability & 231 & $0-6$ years & 39 \\
Learning disability & 52 & $6-10$ years & 110 \\
Autism spectrum disorder & 127 & $11-14$ years & 147 \\
Hearing impairment & 28 & $15-18$ years & 82 \\
Visual impairment & 23 & 18 years and older & 33 \\
Students with language and speech difficulties & 60 & & \\
Gifted or talented students & 5 & \\
Attention deficit hyperactivity disorder & 26 & \\
Orthopedic disability & 42 & \\
Students with chronic disease & 17 & \\
Students with emotional adjustment difficulties & 8 & \\
Students with social adjustment difficulties & 15 & \\
Students with disabilities in more than one area & 28 & & \\
\hline
\end{tabular}

When Table 2 is examined, it is seen that 295 teachers work in the disability group and the total number of people in the age group of the students they work with. 231 of the teachers work with individuals with intellectual disability, 127 with autism spectrum disorder, and 60 with language and speech difficulties. 147 of the teachers work in the 11-14 age group, 110 in the 6-10 age group, and 82 in the 15-18 age group.

\section{Data collection tools}

As data collection tools in the research; the Demographic Information Form and F-BIT Knowledge Test Form developed by the researchers were used.

\section{Demographic information form}

It was developed to determine the demographic information of teachers in the field of special education participating in the study. In this form prepared by the researchers, teachers in the field of special education; Information on age, gender, place of work, disability group, age group of students with special needs, graduation status, department from which he graduated, education related to special education, years of service, and training in behavioral intervention techniques were given.

\section{F-BIT knowledge test form}

The test is to be applied by the researchers to teachers working as special education teachers in various provinces of Turkey; It was developed to determine teachers' knowledge levels about behavioral intervention techniques that are frequently used in behavioral treatment. With this test, the knowledge levels of the teachers in the 
field of special education about the techniques frequently utilized in increasing the appropriate behavior in the students and reducing-eliminating the problem behaviors were determined and it was investigated whether the knowledge levels changed according to the demographic variables. The F-BIT Knowledge Test consists of a total of 33 questions, including 22 multiple-choice questions prepared in vignette format and 11 questions prepared in open-ended question form. Multiple choice questions are questions structured with more than one answer option, and tests created with these questions can be used to measure success (Baykul, 2000; cited in Büyüköztürk et al., 2016). The multiple-choice questions written for the developed F-BIT Knowledge Test were created with vignettes. In vignettes tests, the problem situations are briefly defined and the test takers are allowed to portray the situation clearly (Jeffries \& Maeder, 2004; Sazak-Pınar, 2009). According to Jeffries \& Maeder (2004) and (Kish, 2004), vignettes are defined as incomplete short stories that are written to reflect, in a less complex way, real-life situations to encourage discussions and potential solutions to problems where multiple solutions are possible. Studies in the literature emphasize that these stories measure information more reliably and objectively than surveys and interviews (Alexander \& Becker, 1978; Sazak-Pınar, 2009; Brovelli et al., 2014). In the questions written for the F-BIT Knowledge Test, attention was paid to keeping the stories short, clear, and understandable.

F-BIT Knowledge Test also includes 11 open-ended questions. Open-ended questions are unstructured questions that are preferred when participants are asked to answer freely, and they have the advantage of getting unplanned answers from participants. The variation in the answers provided contributes to obtaining broader and more detailed information about the measured area. Fill-in-the-blank questions are one of the ways to answer openended questions. In cases where the answer can be given with one or more words, questions are asked to the participant, leaving appropriate space for the answer (Büyüköztürk et al., 2016). In this study, filling in the blanks was preferred as a way of answering open-ended questions prepared to determine the knowledge level of teachers in the field of special education about the techniques frequently utilized in behavioral treatment. A total of 11 open-ended questions at the comprehension level, one for each technique, are in the form of a part of the F-BIT Knowledge Test, called the Short Answer Questionnaire. For the content validity of these 11 short-answer questions, opinions of experts in measurement, evaluation, and special education were taken. For open-ended questions, field experts are asked to evaluate the question items in terms of content validity and the items can be rearranged in line with their suggestions (Büyüköztürk et al. 2016). The questions, which were rearranged and shaped according to expert opinion, were added to the F-BIT Knowledge Test and distributed to teachers in the special education field to be answered simultaneously. Participants were asked to answer the questions by writing the name of the technique they thought was appropriate in the space provided for the answer.

The questions in the developed F-BIT Knowledge Test were delivered to 350 teachers working as special education teachers in the field of special education in 10 provinces of Turkey and were answered appropriately by 295 of them.

Table 3. Behavioral intervention techniques in the F-BIT knowledge test

\begin{tabular}{ll}
\hline Teaching and promoting appropriate behaviors & Reducing-eliminating problem behaviors \\
\hline Negative Reinforcement & Differential Reinforcement \\
Positive Reinforcement & Non-Conditional Reinforcement \\
Symbol Reinforcement & Extinction \\
Behavior Contract & Response cost \\
& Time-out \\
& Overcorrection \\
& Delivering punishing stimulus \\
\hline
\end{tabular}

When Table 3 is examined, it is seen that behavioral intervention techniques are divided into two teaching or increasing appropriate behaviors and reducing or eliminating problem behaviors. Among these intervention techniques, the most frequently utilized techniques for gaining or increasing appropriate behaviors are; positive and negative reinforcement, symbol reinforcement, and a behavior contract are included. In the study, among the most frequently used techniques for reducing or eliminating problem behaviors; Differential reinforcement, non-conditional reinforcement, extinction, response cost, time-out, overcorrection, and delivering impulsive stimulus techniques are included; In the F-BIT Knowledge Test, questions about these techniques were created.

To carry out studies on the validity and reliability of the F-BIT Knowledge Test, the test was delivered to 350 special education teachers. Participants were asked to answer 33 questions in the test, including 22 multiple choice and 11 open-ended questions, without skipping any questions. The answers of 295 of the participating teachers who answered the test completely were evaluated. While the test was being evaluated, 1 point was given for correct 
answers and 0 points for incorrect answers. Item analysis statistics are included. When the F-BIT Knowledge Test item difficulty scores were examined; 9 items are very easy, 9 items are very easy, 9 items are medium and 6 items are extremely difficult. As a result of the analysis, the item difficulty score of the 33-item test was calculated as 0.64 and the item discrimination score as 0.33 . The overall test was found to have moderate difficulty and fairly good discrimination. For the reliability of the 33-item F-BIT Knowledge Test, the Cronbach alpha internal consistency coefficient was calculated as 0.74 and the test was found to be quite reliable. It has been accepted that the measurement tool developed according to the data obtained from all analysis for the F-BIT Knowledge Test is reliable, and valid.

\section{Data collection process}

In the research, the following stages were passed in the process of applying the SIK-DMT Knowledge Test to the participants:

1. Giving Preliminary Information to the Teachers: Before the application, the participant teachers were explained about the test, how they should apply the test and what points they should pay attention to while applying the test. Teachers were presented with a research permit approved by the Ministry of National Education and it was reported that an ethical approval document was received for the research.

2. Delivering the Test to Teachers: The F-BIT Knowledge Test was administered to teachers face-to-face, and via social media (e-mail, Facebook, Instagram). All participants who could be reached were given 3 days for the application. The contact addresses of the researcher were given to the participants so that they could reach them when they had questions.

3. Test Collection: Three days after the test was delivered to the participant, the participant teachers were contacted again. Within the given time, the forms were taken back from those who completed the F-BIT Knowledge Test, and after 1 more day was given to the teachers who requested additional time, all the forms were collected.

4. Delivery of Answer Key and Research Results to Teachers: Each participant who took the F-BIT Knowledge Test was given an answer sheet upon request. In addition, it was informed by the practitioner to the participants that they would be informed about the results at the end of the research upon their request.

\section{Data analysis}

After the data were collected, the data collected with the F-BIT Knowledge Test, and Demographic Information Form were prepared for analysis. Demographic information of 295 teachers and the total scores they got from the test were analyzed with SPSS to answer the research questions. The determination of the knowledge levels of the teachers in the special education field about the behavioral intervention techniques that are frequently used in behavioral treatment was made according to the total score they got from the F-BIT Knowledge Test and it was examined whether the knowledge levels of the teachers changed according to the demographic information. Kruskal-Wallis-H test, Mann-Whitney-U test, Kolmogorov-Smirnov and Shapiro-Wilk test techniques were employed in the analysis and interpretation of the research data.

\section{Results}

In this part of the study, which aims to investigate the knowledge levels of teachers in the field of special education about behavioral intervention techniques that are frequently used in behavioral treatment, the results of the statistical analysis carried out in line with the aims of the research are included.

1. Knowledge levels of teachers in the field of special education on behavioral intervention techniques frequently used in behavioral treatment

Table 4. Descriptive statistics of F-BIT knowledge test total scores

\begin{tabular}{lcccc}
\hline & Minimum & Maximum & Average & Standard deviation \\
\hline Overall test & 5 & 30 & 21,00 & 4,74 \\
\hline
\end{tabular}

Analysis were made considering the scores of the teachers in the special education field in the study group from the F-BIT Knowledge Test. The lowest score that can be taken from the test by the participants was 0 , the highest score was 33 , the average of the scores obtained was 21 , the standard deviation was 4.74 , the lowest score was 5 , and the highest score was 30 . The descriptive statistics of the total scores for the 33-item F-BIT Knowledge 
Test are given in Table 4. When Table 4 is examined, it is seen that the knowledge level of the teachers in the field of special education about the behavioral intervention techniques that are frequently employed in behavioral treatment is limited.

2. The differences in the knowledge levels of the teachers in the field of special education about the behavioral intervention techniques commonly used in behavioral treatment by demographic characteristics

To examine whether the knowledge levels of the teachers change according to gender, age, place of work, inadequacy group, age group of the students, department graduated, educational status of special education, and training in behavioral intervention techniques, it was first tested whether the scores obtained from the test were normal or not. The distribution was found to be not normal. The normality analyses for the distributions of the scales are given in Table 5.

Table 5. Normality analysis for scale distributions

\begin{tabular}{cllll}
\hline & \multicolumn{2}{l}{ Kolmogorov-Smirnov $^{\mathrm{a}}$} & Shapiro-Wilk \\
\cline { 2 - 5 } & Statistics & $\mathrm{Sd}$ & Statistik & $\mathrm{Sd}$ \\
\hline Overall test & .098 & 295 & .972 & 295 \\
\hline$*_{p=.000}$ & & &
\end{tabular}

As indicated in Table 5, when the significance values obtained as a result of Kolmogorov-Smirnov and Shapiro-Wilk tests performed to test the normality of the scales were examined, it was found that the distribution of the test overall was not normally distributed $(p<.05)$. According to the results of the analysis, it was decided to apply nonparametric tests to the test. Significance analysis were carried out in line with the data obtained from the teachers' gender, age, place of work, disability group, age group of the students they work, the department they graduated from, their educational status regarding special education, and their status of receiving behavioral intervention techniques training, and the answers given by the teachers to the test. The Mann-Whitney U test regarding the difference between gender and the scale is given in Table 6.

Table 6. Mann-Whitney-U Test for the difference between gender variable and scale

\begin{tabular}{ccccccc}
\hline Scale & Gender & $\mathrm{n}$ & Average & Rank total & $\mathrm{U}$ & $p$ \\
\hline \multirow{2}{*}{ Overall test } & Female & 169 & 154,01 & 26028,50 & \multirow{2}{*}{9630,50} & .16 \\
\hline$*_{p}<0.5$ & Male & 126 & 139,93 & 17631,50 & &
\end{tabular}

When the data in Table 6 were examined, no significant difference was found between the test and the gender variable as a result of the Mann-Whitney-U test, which was performed to determine whether there was a significant difference between the F-BIT Knowledge Test and the gender variable $(\mathrm{p}<.05)$. The Kruskal-Wallis test regarding the difference between the age variable and the scale is given in Table 7.

Table 7. Kruskal-Wallis Test regarding the difference between age variable and test

\begin{tabular}{|c|c|c|c|c|c|c|c|}
\hline Scale & Age & $\mathrm{n}$ & Rank average & $\mathrm{Sd}$ & $\chi^{2}$ & $p$ & Significant difference \\
\hline \multirow{3}{*}{ Overall test } & 24 years and under & 53 & 162,99 & \multirow{3}{*}{2} & \multirow{3}{*}{13,044} & \multirow{3}{*}{.001} & \multirow{3}{*}{$\begin{array}{l}1-3 \\
2-3\end{array}$} \\
\hline & $25-35$ years & 187 & 154,57 & & & & \\
\hline & 36 years and older & 55 & 111,20 & & & & \\
\hline
\end{tabular}

According to the data in Table 7, as a result of the Kruskal-Wallis-H test performed to determine whether the mean rankings of the F-BIT Knowledge Test show a significant difference according to the age variable of the teachers, the difference between the averages of the rankings of the test and age variable groups was found to be statistically significant. $(\chi 2=13.044, \mathrm{p}<.05)$. After this process, after Kruskal-Wallis-H, complementary comparison techniques were employed to determine which groups caused the significant difference determined in the test. Since there is no special test technique utilized for this purpose, Mann-Whitney- $U$ test, which is preferred in pairwise comparisons, was applied. The significant difference determined as a result of the analysis was between the ages of 24 and below and those aged 36 and above in favor of those aged 24 and under $(U=958.00, p<.05)$, between the ages of 25-35 and those aged 36 and above, between the ages of 25-35. was found to be in favor ( $U=3618,00$, $\mathrm{p}<.05)$. According to these findings, it is seen that the level of knowledge of the teachers in the field of special education about the behavioral intervention techniques that are frequently used in behavioral treatment increases as the age of the teachers gets younger. The Kruskal-Wallis test regarding the difference between the place variable and the scale is given in Table 8. 
Table 8. The Kruskal-Wallis Test for the difference between the workplace variable and the test

\begin{tabular}{|c|c|c|c|c|c|c|c|}
\hline Scale & Workplace & $\mathrm{N}$ & Rank average & $\mathrm{sd}$ & $\chi^{2}$ & $p$ & $\begin{array}{l}\text { Significant } \\
\text { difference }\end{array}$ \\
\hline \multirow{4}{*}{$\begin{array}{l}\text { Overall } \\
\text { test }\end{array}$} & Special education practice school & 103 & 144,71 & \multirow{4}{*}{3} & \multirow{4}{*}{19,106} & \multirow{4}{*}{.000} & \multirow{4}{*}{$\begin{array}{l}1-3 \\
2-3 \\
2-4 \\
3-4\end{array}$} \\
\hline & $\begin{array}{l}\text { Special education business applica- } \\
\text { tion center }\end{array}$ & 52 & 114,08 & & & & \\
\hline & Classroom of special education & 66 & 182,18 & & & & \\
\hline & Other & 74 & 145,93 & & & & \\
\hline
\end{tabular}

According to the data in Table 8, the Kruskal-Wallis-H test was utilized to determine whether the mean rankings of the F-BIT Knowledge Test show a significant difference according to the variable of the place where the teachers work. According to the test results, the difference between the mean rankings of the studied location variable groups in all of the scales was found to be statistically significant $(\chi 2=18,646, \mathrm{p}<.05)$. After this process, complementary comparison techniques were employed to determine from which groups the significant difference was determined in the whole of the scales after Kruskal-Wallis-H originated. Since there is no special test technique used for this purpose, the Mann-Whitney-U test, which is preferred in pairwise comparisons, was applied. The significant difference found in the test; Between special education practice school and special education class in favor of special education class $(\mathrm{U}=2580,00, \mathrm{p}<.05)$, between special education business application center and special education class in favor of Special Education Class $(U=895.50, \mathrm{p}<.05) .05)$ was found in favor of the other group between the special education job application center and the other group ( $U=1494.00, p<.05)$, and in favor of the special education class between the special education class and the other group ( $U=1848.50 \mathrm{p}<.05)$.).

According to these results, it is seen that the level of knowledge of the teachers in the field of special education about the behavioral intervention techniques that are frequently used in behavioral treatment differs according to the place where the teachers work. After the comparison, it was determined that the knowledge level of the teachers working in the special education classroom was higher than the teachers in the special education practice school, special education job application center, and other categories. When the difference between the special education job application center and the teachers in the other category was examined, it was determined that the knowledge level of the teachers in the other category was higher than the teachers in the special education job application center. Table 9 . shows the data on the difference between the disability group variable and the scale. The variable "The disability group you are working with" is a question that can be marked with more than one option, and therefore, significance tests could not be applied. The average scores of the groups are given in Table 9.

Table 9. Average scores of the groups regarding the difference between the disability group variable and the scale

\begin{tabular}{lcc}
\hline Worked for disability group & $\mathrm{n}$ & $\overline{\mathrm{X}}$ \\
\hline Intellectual disability & 231 & 21,37 \\
Learning disability & 52 & 21,00 \\
Autism spectrum disorder & 127 & 20,50 \\
Hearing impairment & 28 & 21,28 \\
Visual impairment & 23 & 20,74 \\
Students with language and speech difficulties & 60 & 20,25 \\
Gifted or talented students & 5 & 22,20 \\
Attention deficit hyperactivity disorder & 26 & 19,23 \\
Orthopedic disability & 42 & 22,27 \\
Students with chronic disease & 17 & 20,06 \\
Students with emotional adjustment difficulties & 8 & 21,25 \\
Students with social adjustment difficulties & 15 & 20,07 \\
Students with disabilities in more than one area & 28 & 21,18 \\
\hline
\end{tabular}

When the data in Table 9 are examined, the teachers working with the "orthopedic disability" group got the highest score with an average of 22.27 , and the teachers working with the "attention deficit and hyperactivity disorder" disability group got the lowest score with an average of 19.23 points. According to these results, it is seen that the level of knowledge of the teachers in the field of special education about the behavioral intervention techniques that are frequently employed in behavioral treatment differs according to the disability group in which the teachers work. After the comparison, it was determined that the level of knowledge of the teachers working with the disability group of "attention deficit and hyperactivity disorder" about the behavioral intervention techniques frequently used in behavioral treatment was the lowest, and the level of knowledge of the teachers working 
with the "orthopedic disability" group was the highest. Data regarding the difference between the student age group variable studied and the scale is given in Table 10. The variable of the student age group studied is a question that can be selected more than one option. Therefore, significance tests could not be applied. The average scores of the groups are given in the table below.

Table 10. Average scores of the groups regarding the difference between the student age group variable and the scale

\begin{tabular}{lcc}
\hline Student age group & $\mathrm{n}$ & $\overline{\mathrm{X}}$ \\
\hline 0-6 years & 39 & 20,31 \\
6-10 years & 110 & 21,01 \\
$11-14$ years & 147 & 20,56 \\
$15-18$ years & 82 & 20,71 \\
18 year and older & 33 & 20,97 \\
\hline
\end{tabular}

When the data in Table 10 are examined, in the test, teachers in the "6-10" age group got the highest score with an average of 21.01 points, while teachers in the "0-6" age group got the lowest score with an average of 20.31 points. According to these results, it is seen that the level of knowledge of the teachers in the field of special education about the behavioral intervention techniques that are frequently employed in behavioral treatment differs according to the age group of the students in which the teachers work. After the comparison, it was determined that the level of knowledge of the teachers working with the "0-6" age group about the behavioral intervention techniques frequently used in behavioral treatment was the lowest, while the knowledge level of the teachers working with the "6-10" age group was determined as the highest. Table 11 shows the data on the difference between the variable of the department you graduated from and the scale.

Table 11. Kruskal-Wallis Test regarding the difference between the scale and the graduated department variable

\begin{tabular}{llcccccc}
\hline Scale & Graduated department & $\mathrm{n}$ & $\begin{array}{c}\text { Rank aver- } \\
\text { age }\end{array}$ & sd & $\chi^{2}$ & $p$ & Significant difference \\
\hline \multirow{3}{*}{ Overall test } & Teacher for intellectual disability & 130 & 167,32 & & & & $1-2$ \\
\cline { 2 - 5 } & General Education Teacher & 91 & 110,90 & 25,385 & .000 & $2-3$ \\
\cline { 2 - 5 } & Other & 74 & 159,68 & & & & $2-3$ \\
\hline
\end{tabular}

According to the results of the Kruskal-Wallis-H test in Table 11, the difference between the mean rank of the graduated department variable groups in all of the scales was found to be statistically significant $(\chi 2=25.385$, $\mathrm{p}<.05)$. The Mann-Whitney-U test was applied to determine which group caused the significant difference determined throughout the scale. The significant difference found as a result of the analysis was found to be in favor of teaching the mentally handicapped between teaching for the mentally handicapped and primary school teacher $(U=3667.50, p<.05)$, and between primary school teaching and other teaching positions in favor of other teachers $(U=2238.50, p<.05) .05)$. According to these findings, it is seen that the level of knowledge of the teachers in the field of special education about behavioral intervention techniques differs according to the department from which the teachers graduated. After the comparison, it was determined that the knowledge level of the teaching of the mentally handicapped is higher than that of the classroom teacher. When the difference between the class teacher and the teachers in the other category was examined, it was determined that the knowledge level of the teachers in the other category was higher than that of the classroom teacher. The Mann-Whitney U test for the difference between the variable of the type of special education received and the is given in Table 12.

Table 12. Mann-Whitney U-Test regarding the difference between the variable of the type of special education received and the test

\begin{tabular}{clccccc}
\hline \multirow{2}{*}{ Scale } & $\begin{array}{l}\text { Type of special education } \\
\text { received }\end{array}$ & $\mathrm{n}$ & Average & Rank total & $\mathrm{U}$ & $p$ \\
\hline \multirow{2}{*}{ Overall test } & $\begin{array}{l}\text { Special education under- } \\
\text { graduate program }\end{array}$ & 183 & 170,12 & 31131,50 & \multirow{2}{*}{6200,50} & .000 \\
\cline { 2 - 5 } & Other programs & 112 & 111,86 & 12528,50 & & 0 \\
\hline
\end{tabular}

According to the data in Table 12, as a result of the Mann-Whitney-U test performed to determine whether there is a significant difference between the test and the special education type variable, a significant difference was found between the test and the special education type variable $(U=6200.50, p<.05)$. When the averages taken from the test are examined, it is seen that the significant difference found is in favor of the "special education undergraduate program". According to these findings, it is seen that the level of knowledge of the teachers in the 
field of special education about the behavioral intervention techniques that are frequently utilized in behavioral treatment differs according to the training of the teachers regarding special education. After the comparison, it was determined that the knowledge level of the teachers with a special education license was higher than the teachers in the other programs' category. Table 13. includes data on the difference between the behavioral intervention techniques training variable and the scale.

Table 13. Mann-Whitney-U Test on the difference between behavioral intervention techniques training variable and scales

\begin{tabular}{llccccc}
\hline \multirow{2}{*}{ Scale } & $\begin{array}{l}\text { Behavioral intervention } \\
\text { techniques training }\end{array}$ & $\mathrm{n}$ & Average & Rank total & $\mathrm{U}$ & $P$ \\
\hline \multirow{2}{*}{ Overall test } & Yes & 212 & 162,82 & 34518,50 & \multirow{2}{*}{5655,500} & .000 \\
\cline { 2 - 6 } & No & 83 & 110,14 & 9141,50 & & \\
\hline
\end{tabular}

According to the data in Table 13, the Mann-Whitney-U test was used to determine whether there was a significant difference between the test and the variable of behavioral intervention techniques training. As a result of the test, a significant difference was found between the test and behavioral intervention techniques training variable $(\mathrm{U}=5655,500, \mathrm{p}<.05)$. When the averages taken from the test are examined, it is seen that the significant difference detected is in favor of the participants who received behavioral intervention techniques training. According to these findings, it is seen that the level of knowledge of the teachers in the field of special education about behavioral intervention techniques, which are frequently utilized in behavioral treatment, differs according to their training in behavioral intervention techniques. After the comparison, it was determined that the knowledge level of the teachers who received behavioral intervention techniques training was higher than the teachers who did not.

\section{Discussion}

This study, it was aimed to determine the knowledge level of teachers in the field of special education about behavioral intervention techniques that are frequently used in behavioral treatment. At the end of the study, it was found that the knowledge level of the teachers in the field of special education about the behavioral intervention techniques frequently utilized in the behavioral treatment of their students was limited. The lowest score received by the teachers was calculated as 5 and the highest score was 30 . The mean of the scores obtained was determined as 21 , and the standard deviation was found to be 4.74. As a result of these data obtained, it is found that the knowledge level of the special education teachers about the behavioral intervention techniques that are frequently used in behavioral treatment is at a moderate level, but the range of knowledge levels is very wide.

When the literature is examined, no research can be found to determine the knowledge level of teachers in the field of special education about behavioral intervention techniques. On the other hand, studies are examining the knowledge levels of teachers about classroom management, and it is seen that the data of these studies were collected with the Classroom Management Knowledge Test developed by Güner (2010). Studies (Alatl1, 2014; Güner, 2010; Iş1kgöz et al., 2018) have shown that the classroom management knowledge level of general and special education teachers is limited. When the Classroom Management Knowledge Test items are examined, some questions include questions about the rewarding technique in behavioral theory. The results of the research on classroom management in the literature support the low level of knowledge of teachers about behavioral intervention techniques, which was obtained from this study.

In this study, answers to two questions were sought. The first is whether the knowledge level of teachers working in the field of special education about behavioral treatment techniques varies according to demographic characteristics (gender, age, place of work, disability group, age group of students, department from which they graduated, educational status of special education and receiving behavioral intervention techniques training). that it does not change. When the results obtained are examined, it is seen that there is no difference according to gender in the level of knowledge of the participant teachers about the behavioral intervention techniques that are frequently utilized in behavioral treatment, and the knowledge level of the teachers' increases as the age of the teachers decreases (between 24 and 36 years old and above in favor of 24 years old, and between 25-35 years old in favor of 24 years old and above). between the ages of 25-35 and between the ages of 36 and 36 (in favor of those aged 25-35). This result is in parallel with the results of the study (Alatlı, 2014; Güner, 2010; Işıkgöz et al., 2018) examining the knowledge levels of teachers about classroom management in the literature. In his study, Alatl (2014) determined that there was no significant difference in the age variable, but the Classroom Management Knowledge Test mean scores of teachers whose age was less than 25 were higher than the mean scores of other age groups. In this situation; The recent graduation of teachers and the fact that their undergraduate knowledge is up-to-date and new are considered as factors. Işıkgöz et al. (2018), in their study, examined whether the knowledge 
levels of classroom teachers about classroom management changed according to the age variable, and they determined that there was no significant difference. However, they determined that the average scores of the classroom teachers in the 25-45 age range from the classroom management knowledge test were higher than the average scores of the classroom teachers in the 46-59 age range. This situation supports the results of the research. In addition, one of the remarkable results of Şenay's (2011) study; problem behaviors are frequently seen in the classrooms of teachers with less seniority. It was stated in the study that younger teachers may have less experience and may encounter more behavioral problems, therefore they may need more information on intervention techniques to cope with problem behaviors. From this point of view, it is thought that the need for self-development of young teachers about behavioral treatment may be effective in a higher level of knowledge.

In this study, it was determined that the knowledge level of the teachers of the mentally handicapped was higher than the classroom teachers in the examination made according to the department from which the teachers graduated. When the difference between the classroom teachers and the teachers in the other category is examined, it has been determined that the knowledge level of the teachers in the other category (such as preschool teachers, teachers for the visually impaired and hearing impaired) is higher than the classroom teachers. The study of Alatli (2014); compared the knowledge of special education and general education teachers and determined that special education teachers had more knowledge about classroom management than general education teachers. This result is in parallel with the results of the study. This result is in line with the fact that the teachers in the other category in the study are also graduates of special education. At this point, an important limitation of the study is that the knowledge levels of the teachers who graduated from pre-school teaching about the behavioral intervention techniques that are frequently used in behavioral treatment were not examined separately. For this reason, it is recommended to examine the knowledge levels of the teachers who graduated from the undergraduate programs of the Education Faculties about the behavioral intervention techniques that are frequently used in behavioral treatment in future studies.

It is thought that the higher level of knowledge of the teachers who graduated from special education programs about the techniques frequently utilized in behavioral treatment may be related to the course content that these teachers took in their undergraduate education. The course content of the special education teaching undergraduate program includes the "Applied Behavior Analysis (ABA)" course for the behavioral treatment of students with special needs. Although the scope of this course is quite wide, there is detailed information about the behavioral treatment of students with special needs. This is considered as one of the reasons for the significant difference in teacher knowledge levels.

In this study, according to the variable where teachers work; It has been determined that the knowledge level of the teachers working in the special education classroom is higher than the teachers working in the special education practice school, special education job application center and other categories. When the difference between the special education job application center and the teachers in the other category was examined, it was determined that the knowledge level of the teachers in the other category was higher than the teachers in the special education job application center. It can be said that the level of needs of students in special education classes is generally mild. It is known that students with mild intellectual disabilities are mostly educated in inclusive environments and special education classes. (Camadan, Özer \& Şen, 2011). From this point of view, considering that the behavioral needs of the students in special education classes are generally mild, for the results of the research; It is thought that teachers in the field of special education may want to change mildly problem behaviors more and make an effort to change them, therefore they may have reached more information.

In this study, when the teachers working with the disability group were examined, it was determined that the teachers working with the ADHD disability group had the lowest level of knowledge about the behavioral intervention techniques that are frequently employed in the behavioral treatment of students with special needs, and the level of knowledge of the teachers working with the orthopedic disability group was the highest. There is no research data that can be compared for this situation in the literature. Considering that most of the participant teachers were working with more than one disability group at the same time, they made multiple markings for the relevant variable, it is thought that this result alone may not be striking and meaningful. For this reason, it is recommended that disability groups should be examined individually in future studies.

In the study, the level of knowledge of the teachers working with the 0-6 age group about the behavioral intervention techniques that are frequently used in behavioral treatment was determined as the lowest, and the knowledge level of the teachers working with the 6-10 age group was determined as the highest. There is no research data that can be compared for this situation in the literature. Mangione and Speth (1998) determined in their studies that first-grade students experience problems when entering an environment with community and Copyright (C) 2022 by IJSSER

ISSN: 2149-5939 
rules for the first time (Yoleri \& Tanış, 2014). For students, there are various rules to be followed in this new environment, intense course objectives, and responsibilities to achieve (Dinçer, 2005; Yoleri \& Tanış, 2014). The adaptation process of students to school not only does not affect academic achievement but also causes students to experience behavioral problems. It is possible to encounter research results showing this in the literature (Brooks-Gunn \& Duncan, 1997; Duncan et al., 2007; Entwisle \& Alexander, 1993; McLoyd, 1998; Wertheimer \& Croan, 2003; Uzun \& Alat, 2014). From this point of view, it can be said that it is important for students and teachers because it is the first year of school and starting school for the 6-10 age group, which coincides with the primary school period. It is thought that in the primary school process, where social cohesion and academic foundations are laid, teachers may need more information in terms of behavioral intervention, and in this context, the need may have positively affected teacher knowledge levels.

When an examination was made according to the teachers' training in behavioral intervention techniques, it was determined that the knowledge level of the teachers who received training in behavioral intervention techniques was higher than the teachers who did not receive training. It is thought that the significant difference between the participants who received and did not receive training in behavioral intervention techniques caused an increase in the level of knowledge in parallel with the training they received on behavioral intervention techniques. It is known that the education received in a subject increases the knowledge and competence of individuals. Some research results in the literature to increase the knowledge-efficacy level of teachers also support that various educational supports and training of teachers have a positive effect on their knowledge and/or competence (Güner, 2010; Çitil, 2016; Güner-Yıldız \& Kurtova, 2017; Timuçin, 2008).

The knowledge level of the teachers who received behavioral intervention techniques training on the intervention techniques frequently used in behavioral treatment; It is thought that the content, duration, and scope of the training received may differ according to the scope. To obtain information about this situation during the research process, questions were asked to the teachers in the Demographic Information Form, but clear information about the content, duration, and scope of the training they received on behavioral intervention techniques could not be obtained from the participating teachers, therefore no evaluation could be made on this subject. It is recommended that comprehensive evaluations be made according to these variables in future studies.

It is thought that the findings obtained from the research will make important contributions to the studies and applications in the literature. On the other hand, this study has limitations. It is limited to 295 teachers working in the field of special education, who are working in 10 provinces of Turkey and can be reached, volunteering to fill the F-BIT Knowledge Test, and the teacher's knowledge level about the techniques frequently employed in behavioral treatment is included in these limitations. It has been very difficult to reach volunteer teachers who are graduates of the field during the application process of the test. It has been observed that this situation is caused by the fact that teachers generally work outside the field and are paid. Some of the teachers reached found the number of questions in the F-BIT Knowledge Test too high and did not want to contribute by stating that they did not have time. Some of the teachers also examined the test and agreed to fill it out, saying that the case studies would refresh their knowledge, but they did not want to fill in the blanks. Another striking situation among the participating teachers is their reactions to the evaluation of their performance. Some teachers stated that they do not want to be held solely responsible for the negative situations experienced in classrooms and schools, and they do not want to fill the test because of the fear that they will get a reaction by determining their level of knowledge. This situation negatively affected the application of the test to more teachers.

Another limitation is that the test does not include techniques to prevent problem behaviors. It is known that the best thing to do to avoid a problem is to prevent it from occurring. In behavioral treatment, priority is given to making various adaptations to prevent problem behaviors (Özmen, 2017). In the first development phase of F-BIT developed in the study, techniques for preventing problem behaviors were also included. However, the test obtained was considered to be quite long, and it was predicted that teachers would be distracted during a long test answering period and perhaps avoid answering the test. For this reason, the scope of F-BIT developed in the research was limited to the behavioral treatment techniques that were determined to be used frequently in the literature.

Despite the limitations mentioned above, the research is considered important in that it is the first research that determines the knowledge levels of teachers in the field of special education about behavioral intervention techniques that are frequently employed in behavioral treatment. It is thought that the study will contribute to future studies with the results obtained and the F-BIT Knowledge Test brought to the field. In addition, the results of the research emphasize the importance of teacher competence. The results of the high level of knowledge of teachers 
with special education licenses and the fact that the level of knowledge of teachers trained in behavioral intervention techniques is higher than teachers who do not receive training are important in terms of drawing attention to the necessity of increasing the knowledge and competence of teachers in the field of special education.

\section{Author contribution statements}

Author contributed all to the design and implementation of the research, to the analysis of the results and to the writing of the manuscript.

\section{Disclosure statement}

No potential conflict of interest was reported by the authors.

\section{Ethics committee approval}

All responsibility belongs to the researchers. All parties were involved in the research of their own free will. This research has ethical approval from Abant İzzet Baysal University, Ethics Committee of Human Researches in Social Sciences (Date: 24.01.2018; Approval: 2018/16)

\section{References}

Acar, Ç. (2000). Zihin Özürlü Çocuklarla Çalışan Özel Ë̆itim Öğretmenlerinin Sinıflarında Karş̧laşstkları Problem Davranışlarla İlgili Görü̈s ve Önerileri. Yüksek Lisans Tezi. Anadolu Üniversitesi, Eskişehir.

Alatlı, R. (2014). Genel ve özel eğitim ögretmenlerinin sınff yönetimi bilgileri ile sinıf yönetimine ilişkin öz yetkinliklerinin karşılaştırılması. Yüksek Lisans, Ankara Üniversitesi, Eğitim Bilimleri Enstitüsü, Ankara.

Alberto, P., \& Troutman, A. C. (2006). Applied behavior analysis for teachers (pp. 1-474). Upper Saddle River, NJ: Pearson Merrill Prentice Hall.

Aykır, T. (2010). Okul öncesi dönemdeki zihinsel yetersizliği olan ve olmayan çocukların sosyal becerileri ve problem davranışlarının karşılaştırılması. Yüksek Lisans Tezi. Abant İzzet Baysal Üniversitesi, Sosyal Bilimler Enstitüsü, Bolu.

Aymaz, Ü. (2018). Sınıf öğretmenlerinin karşılaştıkları istenmeyen öğrenci davranışları ve kullandıkları başa çıkma yöntemleri. Gaziantep Üniversitesi Eğitim Bilimleri Enstitüsü, Gaziantep.

Atçı, M. (2004). İlköğretim I. Kademe Öğretmenlerinin Sınıf İ̧̧i Problem Davranışlara Yönelik Müdahalelerinin İncelenmesi. Yüksek Lisans Tezi. Çukurova Üniversitesi, Adana.

Baykul, Y. (2000). Egitimde ve psikolojide olcme: Klasik test teorisi ve uygulamasi [Measurement in education and psychology: Classical test theory and application]. Ankara: OSYM yayınları.

Beare, P. L., Severson, S., \& Brandt, P. (2004). The use of a positive procedure to increase engagement on-task and decrease challenging behavior. Behavior modification, 28(1), 28-44.

Büyüköztürk, Ş., K1lıç-Çakmak, E., Akgün, E., Ö., Karadeniz, Ş., Demirel, F. (2016). Bilimsel Araştırma Yöntemleri (21. Baskl). Pegem Akademi: Ankara.

Ceylan, F. (2015). Kaynaştırma öğrencilerinin sergilediği problem davranışlara yönelik sınıf öğretmenlerinin uyguladıkları önleme ve müdahale stratejileri. Yüksek Lisans Tezi, Abant İzzet Baysal Üniversitesi Eğitim Bilimleri Enstitüsü, Bolu.

Chandler, L K. \& DahlquvM, C. M. (20(12). Functional assessment strategies to prevent and remediate challenging behavior in scholl settings. New Jersey: Merill Prentice Hall.

Chezan, L. C., Wolfe, K., \& Drasgow, E. (2018). A meta-analysis of functional communication training effects on problem behavior and alternative communicative responses. Focus on Autism and Other Developmental Disabilities, 33(4), 195205.

Chitiyo, M., Makweche-Chitiyo, P., Park, M., Ametepee, L. K., \& Chitiyo, J. (2011). Examining the effect of positive behaviour support on academic achievement of students with disabilities. Journal of Research in Special Educational Needs, 11(3), 171-177.

Cooper, J. O., Heron, T. E., \& Heward Wl (2007). Applied Behaviour Analysis (Seconded) Columbus OH.

Çankaya, İ., \& Çanakçı, H. (2011). Sınıf öğretmenlerinin karşılaştıkları istenmeyen öğrenci davranışları ve bu davranışlarla başa çıkma yolları. Electronic Turkish Studies, 6(2).

Çitil, M. (2016). Üstün Yetenekli Öğrencilere Sunulan Olumlu Davranışsal Destek Temelli Problem Davranışları Önleyici Sınıf Yönetimi Uygulamaları: Eylem Araştırması. Doktora Tezi. Gazi Üniversitesi, Eğitim Bilimleri Enstitüsü, Ankara.

Entwisle, D. R., \& Alexander, K. L. (1993). Entry into school: The beginning school transition and educational stratification in the United States. Annual review of sociology, 19(1), 401-423.

Erbaş, D. (2001). Gelişimsel Geriliği Olan Çocukların Problem Davranışların Azaltılmasına İşlevsel İletişim Öğretiminin Sönmeyle Birlikte ve Sönme Olmaksızın Uygulanmasının Etkililiğinin Karşılaştırılması. Doktora Tezi. Anadolu Üniversitesi, Eskişehir. 
Erbaş, D. (2002). Problem Davranışların Azaltılmasında Olumlu Davranışsal Destek Planı Hazırlama. Ankara Üniversitesi Eğitim Bilimleri Fakültesi Özel Eğilim Dergisi 2002, 3(2) 41-50.

Güleç, S. (2004). Sınıf Öğretmenlerinin Davranış Değiştirme ve Düzeltme Tekniklerini Kullanma Biçimleri. XIII. Ulusal Eğitim Bilimleri Kurultayında sunulan bildiri (6-9 Temmuz, 1-16), İnönü Üniversitesi, Eğitim Fakültesi.

Güner, N. (2010). Kaynaştırma Uygulamaları Yapılan Sınıflarda Çalışan Öğretmenlerin Sınıf Yönetimi Bilgi Düzeyleri ile Önleyici Sınıf Yönetimi Eğitim Programı'nın Öğretmenlerin Sınıf Yönetimlerine Etkisinin İncelenmesi. Doktora tezi, Ankara Üniversitesi Eğitim Bilimleri Enstitüsü, Ankara.

Güner, N. (2010). Kaynaştırma uygulamaları yapılan sınıflarda çalışan öğretmenlerin sınıfyönetimi bilgi düzeyleri ile Önleyici Sinıf Yönetimi Ĕ̈itim Programı'nın öğretmenlerin sınıf yönetimlerine etkisinin incelenmesi. Doktora tezi, Ankara Üniversitesi Eğitim Bilimleri Enstitüsü, Ankara.

Güner-Yıldız, N., \& Kurtova, C. (2017). Sinıf Sorunlarına Eylem Araştırmasıyla Çözüm Arayışı. İlköğretim Online, 16(1), 7888.

Güner-Yıldız, N., \& Sazak-Pınar, E. (2012). Kaynaştırma Sınıflarındaki Özel Gereksinimli Öğrencilere Yöneltilen Öğretmen Davranışlarının Incelenmesi. International Online Journal of Educational Sciences, 2012, 4(2), 475-488.

Heyvaert, M., Saenen, L., Campbell, J. M., Maes, B., \& Onghena, P. (2014). Efficacy of behavioral interventions for reducing problem behavior in persons with autism: An updated quantitative synthesis of single-subject research. Research in Developmental Disabilities, 35(10), 2463-2476.

Işıkgöz, M., Yiğitsoy, H., \& Çiçekçe, K. (2018). Kaynaştırma yoluyla eğitimine devam eden öğrencisi bulunan sınıf öğretmenlerinin sınıf yönetimi bilgi düzeylerinin incelenmesi: Kayseri ili örneği. Batman Üniversitesi Yaşam Bilimleri Dergisi, 8(1/1), 44-51.

Kapucuoglu-Tolunay, A. (2008). Sinıf Öğretmenlerinin Sinıfta Karşılaştıkları İstenmeyen Öğrenci Davranışları ve Bu Davranışlara Karşı Kullandıkları Başetme Yöntemleri. Yüksek Lisans Tezi, Uludağ Üniversitesi Sosyal Bilimler Enstitüsü, Bursa.

Karasar, N. (1995). Bilimsel Araştırma Yöntemi (7. Baskl). 3A Araştırma Eğitim Danışmanlık Ltd: Ankara.

Keskin, M. A. (2002). Sinıf Öğretmenlerinin Karşılaştıkları İstenmeyen Öğrenci Davranışları ve Kullandıkları Baş Etme Yolları. Yayımlanmamış Yüksek Lisans Tezi, Hacettepe Üniversitesi Sosyal Bilimler Enstitüsü, Ankara.

İftar, G. K., \& Tekin, E. (1997). Tek denekli araştırma yöntemleri. Ankara: Türk Psikologlar Derneği Yayınları.

LeGray, M. W., Dufrene, B. A., Mercer, S., Olmi, D. J., \& Sterling, H. (2013). Differential reinforcement of alternative behavior in center-based classrooms: Evaluation of pre-teaching the alternative behavior. Journal of Behavioral Education, 22(2), 85-102.

Losinski, M., Wiseman, N., White, S. A., \& Balluch, F. (2016). A meta-analysis of video-modeling based interventions for reduction of challenging behaviors for students with EBD. The Journal of Special Education, 49(4), 243-252.

Mangione, P. L., \& Speth, T. (1998). The transition to elementary school: A framework for creating early childhood continuity through home, school, and community partnerships. The Elementary School Journal, 98(4), 381-397.

McLoyd, V. C. (1998). Socioeconomic disadvantage and child development. American psychologist, 53(2), 185.

Morano, S., Ruiz, S., Hwang, J., Wertalik, J. L., Moeller, J., Karal, M. A., \& Mulloy, A. (2017). Meta-analysis of single-case treatment effects on self-injurious behavior for individuals with autism and intellectual disabilities. Autism \& Developmental Language Impairments, 2, 2396941516688399.

Özer, B., Bozkurt, N., \& Tuncay, A. (2014). İstenmeyen öğrenci davranışları ve öğretmenlerin kullandıkları başa çıkma stratejileri. Turkish Journal of Educational Studies, 1(2).

Özmen, R. E. (Ed.). (2017). Olumlu Okul Ortamının Oluşturulması ve Davranışsal Problemlerle Müdahale-Öğrenme Güçlüğü Sınıf İçi Destek Seti 2. Kitap. Eğiten Kitap Yayınları: Ankara.

Ritter, W. A., Barnard-Brak, L., Richman, D. M., \& Grubb, L. M. (2018). The influence of function, topography, and setting on noncontingent reinforcement effect sizes for reduction in problem behavior: A meta-analysis of single-case experimental design data. Journal of Behavioral Education, 27(1), 1-22.;

Rose, L. C., \& Gallup, A. M. (2005). The 37th annual Phi Delta Kappa/Gallup poll of the publics attitudes toward the public schools. Phi Delta Kappan, 87(1), 41-57.

Sazak-Pınar, E. (2009). Kaynaştırma Sınıfı Öğretmenlerinin Sosyal Becerilere İlişsin Beklentileri Ve Sosyal Beceri Öğretim Programının Öğretmen Çıktıları Üzerindeki Etkililiğin İncelenmesi. Doktora Tezi. Ankara Üniversitesi, Ankara.

Sazak-Pınar, E. (2017). Sonuçlara dayalı uygulamalar. Uygulamalı davranış analizi içinde, 401-438.

Sazak-Pınar, E., \& Güner-Yıldız, N. (2017). Genel Eğitim Sinıflarındaki Özel Gereksinimli Öğrencilerin Sergiledikleri Problem Davranışlar ile Davranış Sonrası Öğretmen Tepkilerinin İncelenmesi. Kastamonu Eğitim Dergisi, 25(2), 551-566.

Solomon, B. G., Klein, S. A., Hintze, J. M., Cressey, J. M., \& Peller, S. L. (2012). A meta-analysis of school-wide positive behavior support: An exploratory study using single-case synthesis. Psychology in the Schools, 49(2), 105-121. 
Sönmez, V., \& Alacapınar F.G. (2016). Örneklendirilmiş Bilimsel Araştırma Yöntemleri (4. Baskl). Anı Yayıncılık: Ankara.

Timuçin, U. E (2008). Doğrudan Davranışsal Danışmanlı̆̆ın Birlikte Ĕ̆itim Ortamına Yerleştirilmiş Yetersizliği Olan Öğrencilerin Problem Davranışlarını Azaltmadaki Etkililiği. Doktora Tezi. Gazi Üniversitesi, Ankara.

Uzun, E. M., \& Alat, K. (2014). İlkokul Birinci Sinlf Öğretmenlerinin 4+4+4 Eğitim Sistemi ve Bu Sistem Sonrasında İlkokula Başlayan Öğrencilerin Hazırbulunuşlukları Hakkındaki Görüşleri. Abant İzzet Baysal Üniversitesi Eğitim Fakültesi Dergisi, 14(2), 15-44.

Yılmaz, N. (2008). Dersin Akısını Bozan İstenmeyen Davranışları Yönetme Stratejilerinin İncelenmesi. Erzincan Eğitim Fakültesi Dergisi, 10 (1), 1-38.

Yoleri, S., \& Tanış, H. M. (2014). İlkokul Birinci Sınıf Öğrencilerinin Okula Uyum Düzeylerini Etkileyen Değişkenlerin İncelenmesi. Karabük Üniversitesi Sosyal Bilimler Enstitüsü Dergisi 4(2),

Yumuşak, G., \& Balcı, Ö. (2018). Öğretmenlerin İstenmeyen Öğrenci Davranışları ile Başaçıkma Yöntemleri ve Bu Yöntemlerin Etkililiğine İlişkin Görüşleri. Balıkesir Üniversitesi Sosyal Bilimler Enstitüsü Dergisi 2018, Cilt-Say1: 21-40.

Şenay, K. (2011). Illkögrretim Okulları Birinci Kademede Görevli Yönetici ve Öğretmen Algılarına göre İstenmeyen Öğrenci Davranışları ve Önleme Yöntemleri. Yüksek Lisans Tezi, Maltepe Üniversitesi Sosyal Bilimler Enstitüsü, İstanbul.

Yüksek Öğretim Kurumu [YÖK]. (2021). Özel Eğitim Öğretmenliği Lisans Program1. https://www.yok.gov.tr/Documents/Kurumsal/egitim_ogretim_dairesi/Yeni-Ogretmen-Yetistirme-Lisans-Programlari/Ozel_Egitim_Ogretmenligi_Lisans_Programi.pdf 